\title{
p107 is active in the nucleolus in non-dividing human granulosa lutein cells
}

\section{Green ${ }^{1,2}$, R Chatterjee ${ }^{1}$, H H G McGarrigle ${ }^{1}$, F Ahmed Ah, $^{1,2}$ and N S B Thomas ${ }^{2}$}

\author{
${ }^{1}$ Department of Obstetrics and Gynaecology, Royal Free and UCL Medical School, 96 and \\ 98 Chenies Mews, London WC1E 6HX, UK \\ ${ }^{2}$ Department of Haematology, Royal Free and UCL Medical School, 96 and 98 Chenies Mews, \\ London WC1E 6HX, UK \\ (Requests for offprints should be addressed to N S B Thomas who is now at the Department of \\ Haematological Medicine (Leukaemia Sciences), Guy's, King's, St Thomas' School of Medicine and \\ Dentistry, King's College London, Rayne Institute, 123 Coldharbour Lane, London SE5 9NU, UK; \\ Email: nicholas.s.thomas@kcl.ac.uk) \\ (C Green is now at the Department of Veterinary Basic Sciences, Royal Veterinary College, \\ Royal College Street, London NW1 0TU, UK)
}

\begin{abstract}
Cells are maintained in a quiescent state by members of the retinoblastoma protein family, $\mathrm{pRb}$ and $\mathrm{p} 130$. Both are phosphoproteins and hypophosphorylated forms of $\mathrm{pRb}$ and $\mathrm{p} 130$ bind and repress the activity of $\mathrm{E} 2 \mathrm{~F}$ transcription factors, thereby preventing entry into the cell cycle. Mitogenic stimulation causes activation of cyclin dependent kinases (cdk) that phosphorylate both $\mathrm{pRb}$ and $\mathrm{p} 130$, thereby releasing $\mathrm{E} 2 \mathrm{~F}$ factors which stimulate the transcription of a number of genes that are required for DNA synthesis and for regulating the cell cycle. In non-dividing cells, cdks are maintained in an inactive state by cdk inhibitor proteins such as $\mathrm{p} 27^{\mathrm{Kip} 1}$. The aim of our study was to determine how E2F complexes are regulated during the differentiation of human primary granulosa lutein cells (GLC) of the corpus luteum (CL). The CL is formed in the ovary after ovulation at the terminal stage of folliculogenesis after completion of maturation and differentiation of Graafian follicles. As shown by flow cytometry GLC are not dividing, being predominantly in the $G_{0} / G_{1}$ phase of the cell cycle and, consistent with
\end{abstract}

this, they contain the cdk inhibitor protein, $\mathrm{p} 27^{\mathrm{Kip} 1}$, but not E2F-1 which is normally expressed only in proliferating cells. The GLC do express E2F-4, hypophosphorylated $\mathrm{pRb}, \mathrm{p} 130$ forms 1 and 2 and, surprisingly, hypophosphorylated p107. p107 is normally present only in dividing cells where it regulates E2F activity during the cell cycle. These forms of pRb, p130 as well as p107, together with E2F-4 are all active in that they can bind an E2F DNA-binding site in a pull-down assay. Immunocytochemistry shows that these proteins are expressed in almost all GLC but have different sub-cellular distribution: p107 is concentrated in nucleoli, while p130 and E2F-4 show relatively even nuclear and cytoplasmic distributions. Both $\mathrm{pRb}$ and p130 have been implicated previously in repressing E2F activity in many different cell types during cell cycle arrest in $G_{0} / G_{1}$. We conclude that p107 is active in human primary GLC but its nucleolar localisation would suggest that it represses ribosomal RNA synthesis rather than $\mathrm{E} 2 \mathrm{~F}$ activity. Fournal of Molecular Endocrinology (2000) 25, 275-286

\section{INTRODUCTION}

Ovarian folliculogenesis encompasses sequential events of recruitment and development of primordial follicles, maturation and differentiation of the oocyte with its companion granulosa cells, follicular rupture with release of the mature oocyte by ovulation, formation of fully mature and differentiated corpora lutea (CL) and atresia (reviewed in Hillier et al. 1995). Aberration of one 
or more of these temporal events of gametogenesis, such as follicular arrest, ovulatory dysfunction, or luteal insufficiency may be associated with clinical disorders of unexplained infertility, recurrent miscarriage or menstrual dysfunction. The best treatment for dysovulatory infertility and CL dysfunction is severely compromised due to poor understanding of the complex biology of normal human gametogenesis.

The recent literature emphasises the specific role of cell cycle regulatory proteins in the control of granulosa lutein cell (GLC) maturation and differentiation during folliculogenesis. This is derived largely from null mice models which have altered ovarian phenotypes. For example, mice lacking the cyclin dependent kinase (cdk) activator, cyclin D2, have small ovaries, folliculogenesis arrest at the pre-antral stage of growth and they are infertile (Sicinski et al. 1996). This is similar to hypophysectomised mice as well as mice null for the follicle-stimulating hormone gene $\left(F S H B^{b}\right)$ (Kumar et al. 1997) or the gonadotrophin-releasing hormone gene, GnRH (Mason et al. 1986). These findings suggest that the first stage of folliculogenesis is independent of gonadotrophic support and follicles can grow up to the pre-antral stage without follicle-stimulating hormone (FSH). However, cyclin D2, which is induced by FSH, is critical for further proliferation and maturation of granulosa cells during follicular development. In contrast, in mice lacking the cdk inhibitor, $p 27^{K i p 1}$, follicular growth is not compromised, but there is defective CL formation with failure of granulosa cells to luteinise in response to luteinising hormone $(\mathrm{LH})$ (Kiyokawa et al. 1996). Although the above findings improve our understanding of follicular development and highlight the possible role of expression of cell cycle regulatory proteins and their regulation by hormones during cyclical folliculogenesis in mice, animal data cannot necessarily be extrapolated to humans. In particular, there is a difference in the physiological control of ovarian cycles between primates, which undergo an oestrous cycle, and humans who are mono-ovulatory with a menstrual cycle. Therefore, human studies are warranted to understand better the biology and physiology of human folliculogenesis.

Entry into and exit from the cell cycle are regulated by the retinoblastoma protein, $\mathrm{pRb}$, and its relative, p130 (reviewed in Thomas 1999). These are phospho-proteins that, in their hypophosphorylated state, bind and repress the activity of the E2F family of transcription factors in the nucleus. This is thought to occur because $\mathrm{pRb}$ and $\mathrm{p} 130$ bring with them histone deacetylase that causes gene silencing and thereby prevents cells from entering the cell cycle. The E2F factors are heterodimers of an $\mathrm{E} 2 \mathrm{~F}$ protein $(\mathrm{E} 2 \mathrm{~F}-1$ to -5$)$ together with either DP-1 or DP-2 which activate the transcription of genes, such as DNA pol-a, thymidine kinase and MCM2 that are required for DNA synthesis, and $c d c 2$, cyclin $A$ and $p 107$ that regulate progression through the cell cycle. Thus, whereas $\mathrm{p} 130$ and $\mathrm{pRb}$ are expressed in both quiescent and proliferating cells, the third member of the $\mathrm{pRb}$ family, $\mathrm{p} 107$, is not expressed in quiescent T-lymphocytes, for example, but is in T-lymphocytes proliferating in interleukin-2 (IL2). $\mathrm{pRb}$ also binds other proteins, such as MDM2-p53 and c-Abl, and pRb and p130 repress all three classes of RNA polymerases. Both $\mathrm{pRb}$ and p130 are phosphorylated by the sequential activation of cdk as cells progress from $G_{0}$ through $G_{1}$. Hyperphosphorylation, which occurs by the time cells reach late $G_{1}$, inactivates $p R b$ and $p 130$ and allows cells to progress through the restriction point in late $\mathrm{G}_{1}$ and to complete $\mathrm{S}$-phase. Thereafter, in continuously dividing cells, p107 and pRb are thought to repress $\mathrm{E} 2 \mathrm{~F}$ activity during late $\mathrm{S}$ through $\mathrm{G}_{1 \mathrm{~A}}$. The subcellular distribution of these proteins reflect their activation state: for example, p130 is active and binds E2F-4-DP-1 in the nucleus of quiescent cells, but it is cytoplasmic in proliferating cells.

Data on cell cycle control of human gametogenesis is sparse. Since a granulosa cell is a somatic cell the biological development of human ovarian follicles should logically undergo a complex process of proliferation, replicative senescence and differentiation regulated directly or indirectly by cell cycle proteins such as the retinoblastoma protein, pRb. Bukovsky et al. (1995) studied the levels of expression of $\mathrm{pRb}$ in ovarian tissues during various phases of menstrual cycles. Their data demonstrate that enhanced $\mathrm{pRb}$ expression precedes follicular growth and differentiation in the oocytes as well as the granulosa cells and low levels of $\mathrm{pRb}$ accompany advanced differentiation of these cells. Since the appropriate expression of cyclin D2 is crucial for granulosa cell proliferation in the mouse and the induction of $\mathrm{p} 27^{\mathrm{Kip} 1}$ and $\mathrm{p} 21^{\mathrm{Cip} 1}$ have also been implicated in murine GLC differentiation, these changes would be expected to alter cdk activity and hence the phosphorylation state and E2F-binding activity of the $\mathrm{pRb}$ family of proteins. It is not known whether similar mechanisms operate in human GLC and so we have studied the expression and activity of cell cycle proteins in human GLC obtained from patients undergoing in vitro fertilisation. We show here that the GLC are not dividing, they express $\mathrm{p} 27^{\mathrm{Kip} 1}$, but not E2F-1, and they contain hypophosphorylated $\mathrm{pRb}$ and $\mathrm{p} 130$ 
that bind to an E2F DNA-binding site together with E2F-4. Also, we show that the GLC contain active p107 capable of binding the E2F DNAbinding site. The p107 is present in all cells and has a distinctive nucleolar distribution different from p130.

\section{MATERIALS AND METHODS}

\section{Reagents}

Chemicals were obtained from Sigma-Aldrich Co. Ltd (Poole, Dorset, UK) unless stated otherwise.

\section{Cell isolation and culture}

Granulosa lutein cells were isolated from the follicular fluid obtained from women attending the Assisted Conception Unit. Our study included women undergoing ovarian stimulation for in vitro fertilisation for infertility, and details of the super-ovulation protocol used has been described previously (Ranieri et al. 1998). The primary indications for assisted conception were tubal factor $(20 \%)$, ovulatory factor $(20 \%)$, unexplained infertility $(30 \%)$ or male factor $(30 \%)$. On day 2 of the cycle all patients underwent an ultrasound scan. Basal blood samples were taken on day 2 and further samples were taken on days 3 and 4 for FSH, LH and oestradiol assays. The patients were given a buserelin (a gonadotrophin-releasing hormone agonist) nasal spray $100 \mu \mathrm{g}$ every $4 \mathrm{~h}$ during the day to down-regulate the hypothalamic-pituitary (H-P) axis. The dose was doubled before bedtime and administration of the drug was suspended during the night and restarted in the morning. The total daily dose was usually around $1200 \mu \mathrm{g}$. H-P axis down-regulation was continued for a further 10-12 days, then ovarian stimulation was started with 225 IU purified FSH/day. Follicular growth was monitored by trans-vaginal scans beginning on day 6 of stimulation. The dose of gonadotrophin was titrated according to the ovarian response. Patients who had $>1$ leading follicle of $17 \mathrm{~mm}$ in diameter and 2 of $15 \mathrm{~mm}$ in diameter received $10000 \mathrm{IU}$ human chorionic gonadotrophin (hCG) between days 12 and 14. Granulosa lutein cells were obtained from follicular fluid after oocyte retrieval of the follicles was completed by ultrasound-guided needle aspiration. The GLC in the follicular fluid were disaggregated by passing 30 times through a 25 -gauge needle. This procedure did not cause significant cell death $(22 \% \pm 11 \cdot 5 \%, n=103)$ when carried out in the follicular fluid, but disaggregation of GLC after purification (described below) killed a large proportion of the cells. The disaggregated GLC were centrifuged through Ficoll-Paque (Amersham-Pharmacia Biotech, St. Albans, Herts, UK) (see Devalia et al. 1992) and sedimented at the interface with the mononuclear cells. We tried to remove the contaminating blood cells with immunomagnetic beads, but this led to unacceptable losses of GLC. Instead, the GLC were purified by culturing overnight in RPMI-1640/10\% (v/v) FCS (Life Sciences, Paisley, Scotland, UK). The GLC adhered to the plastic together with the remaining monocytes (5\%-10\% contamination). The neutrophils, most of which die under these conditions, together with the lymphocytes and red cells were removed by aspirating the supernatant. Overall, the purity was $59 \%(n=37)$, but typically GLC of $>90 \%$ purity were used in the experiments described below. We and others have characterised the cell cycle status and the expression of a number of cell cycle proteins in different haemopoietic cell types (reviewed in Thomas 1999). In assays carried out in this study we controlled for the presence of the small proportion of haemopoietic cells in GLC isolates by purifying populations of monocytes, T-lymphocytes and neutrophils, as described below, and analysing the number of each contaminating cell type that was present in each GLC preparation. In this way we could exclude the possibility that the results we obtained were due to the small number of contaminating haemopoietic cells.

Isolation and culture of haemopoietic cells was as described previously (Devalia et al. 1992) and, in each case, the purity of the preparation was determined by standard immunophenotyping and morphology. The purities of samples used for this paper were: monocytes, $85 \%$; T-lymphocytes, $83 \%$; neutrophils, $97 \%$. Where indicated, purified T-cells were cultured at $1 \times 10^{6}$ cells $/ \mathrm{ml}$ in RPMI/10\% (v/v) FCS and stimulated with $1 \mu \mathrm{g} / \mathrm{ml}$ phytohaemagglutinin (PHA) (Glaxo Wellcome, Greenford, Middlesex, UK) for three days. After extensive washing, IL-2 (R \& D Systems, Abingdon, Oxon, UK) was added to a final concentration of $20 \mathrm{ng} / \mathrm{ml}$ and the culture was continued for 3-5 days. Human primary CD34+ haemopoietic progenitor cells were mobilised into the peripheral blood and then isolated and cultured as described previously (Williams et al. 1997a). Cells employed in this study were surplus to patient requirements and were used with ethical approval. Proliferating Daudi B-cells (obtained from Dr Ian Kerr, ICRF, London, UK) were maintained between 2 and $10 \times 10^{5}$ cells $/ \mathrm{ml}$ in RPMI-1640/10\% (v/v) FCS and were diluted to between 2 and $4 \times 10^{5}$ cells $/ \mathrm{ml}$ at least $24 \mathrm{~h}$ before use. 


\section{Steroidogenic metabolism}

The purified granulosa lutein cells were plated out into 24-well plastic culture dishes at a density of $2 \times 10^{4}$ cells per well in $2 \mathrm{ml}$ RPMI-1640 culture medium supplemented with $10 \%(\mathrm{v} / \mathrm{v}) \mathrm{FCS}$. The cells were maintained in culture for $96 \mathrm{~h}$. Cells were cultured in medium alone and in the presence of either pregnenolone or testosterone, both at a concentration of $10 \mu \mathrm{M}$. Aliquots of $100 \mu \mathrm{l}$ were removed at $24-\mathrm{h}$ intervals to monitor the production of progesterone and oestradiol from their respective precursors pregnenolone and testosterone (Darne et al. 1989). Briefly, culture medium containing liberated oestradiol and progesterone was extracted with diethyl ether. The ether was evaporated and the residue dissolved in assay buffer. Aliquots of this buffer were subjected to radioimmunoassay for oestradiol and progesterone content using tritiated tracers (New England Nuclear Life Science Products, Hounslow, UK) and highly specific sheep anti-oestradiol and sheep anti-progesterone antisera (Bioclin Services International, Helsinki, Finland).

\section{Flow cytometry}

The purified GLC were fixed in $70 \%(\mathrm{v} / \mathrm{v})$ ethanol at $-20{ }^{\circ} \mathrm{C}$ and the DNA was stained with propidium iodide (PI). Briefly, the cells were centrifuged at $800 \times \boldsymbol{g}_{\boldsymbol{a v e}}$, the pellet was loosened by gently flicking the tube and the cells were then fixed by dropwise addition of $70 \%(\mathrm{v} / \mathrm{v})$ ethanol, again with gentle agitation. Agitation by vortexing which, for example, works well for lymphocytes and ensures a single cell suspension, should not be used as this causes the fixed GLC to fragment. The cells were stained with PI and flow cytometric analysis of forward scatter (FS), side scatter (SS) and DNA content was carried out with an EPICS Elite flow cytometer (Coulter Electronics, Luton, Beds, UK). Note that the FS compared with SS characteristics of the haemopoietic cells analysed here alters after fixation in $70 \%(\mathrm{v} / \mathrm{v})$ ethanol. For example, neutrophils are no longer separable from $\mathrm{T}$ lymphocytes on the basis of SS. Doublets of cells in $\mathrm{G}_{0} / \mathrm{G}_{1}$ which can appear to be in $\mathrm{G}_{2} / \mathrm{M}$ were excluded as far as possible by only including cells which were within linear gates for forward scatter compared with forward scatter peak and also for PI staining compared with PI peak. As there was one predominant peak in each GLC sample analysed, the percentage of cells in this peak as compared with the number with lower and higher DNA content was determined by setting linear gates.

\section{E2F DNA-binding site pull-down assays and Western blotting}

Pull-down assays were carried out as described previously (Thomas et al. 1998, Van der Sman et al. 1999) with $5 \times 10^{5}-2.5 \times 10^{6}$ GLC or with $1-5 \times 10^{6}$ proliferating or quiescent T-lymphocytes which were lysed in $800 \mu \mathrm{l}$ low salt buffer. Solutions were kept on ice and all manipulations were carried out in a $5{ }^{\circ} \mathrm{C}$ cold-room. The lysate was centrifuged for 2 min at $10000 \times g_{\text {ave }}$, the supernatant was transferred to a fresh tube and the nuclear pellet was then extracted for $20 \mathrm{~min}$ with $80 \mu \mathrm{l}$ of the same buffer containing $450 \mathrm{mM} \mathrm{NaCl}$. After centrifugation for $2 \mathrm{~min}$ at $10000 \times \boldsymbol{g}_{\boldsymbol{a v e}}$, the supernatants were pooled and preabsorbed for $1 \mathrm{~h}$ with $10 \mu \mathrm{g}$ of a $5^{\prime}$ biotinylated, mutant form of the distal E2F doublestranded DNA binding site from the adenovirus type 5 E2a promoter (E2F ${ }^{\text {MUT }}$ : biotin-5'GATCTAGT TTTCGataTTAAATTTGA3') and $20 \mu \mathrm{l}$ monomeric avidin coupled to a methacrylate matrix (Softlink Avidin, Promega, Southampton, UK). After centrifugation at $10000 \times \boldsymbol{g}$ for $10 \mathrm{~s}, 10 \mu \mathrm{g} \mathrm{E} 2 \mathrm{~F}$ wild-type DNA-binding site $\left(\mathrm{E} 2 \mathrm{~F}^{\mathrm{WT}}\right.$ : biotin5'GATCTAGTTTTCGCGCTTAAATTTGA3') and $20 \mu \mathrm{l}$ avidin beads were added to the supernatant which was mixed on a wheel for $1 \mathrm{~h}$. Both sites were used previously for electrophoretic mobility shift assays (Williams et al. 1997a). The beads were centrifuged, washed three times with $800 \mu$ low salt lysis buffer per wash and the proteins bound were solubilised by boiling for $10 \mathrm{~min}$ in $30 \mu \mathrm{l}$ SDS sample buffer containing protease and phosphatase inhibitors (sodium fluoride, sodium orthovanadate, phenylmethylsulphonyl fluoride and di-isopropyl fluoro phosphate). One third of each sample was electrophoresed per gel. These procedures were sufficient to extract all p130, $\mathrm{pRb}$ and $\mathrm{p} 107$ from GLC and none was detected when SDS lysates of the residual nuclear pellets were subjected to Western blotting (data not shown).

Total cell lysates for Western blotting were made by pelleting cells at $400 \times \boldsymbol{g}_{\boldsymbol{\alpha} \text { e }}$ for $7 \mathrm{~min}$, and then boiling for $10 \mathrm{~min}$ in $2 \times \mathrm{SDS}$ sample buffer containing protease and phosphatase inhibitors as described above $\left(50 \mu \mathrm{l} / 1 \times 10^{6}\right.$ cells $)$. Either 1 or $2 \times 10^{5}$ cells were loaded in each lane. The percentages of polyacrylamide gels used were: $6 \%$ for $\mathrm{p} 130, \mathrm{pRb}$ and $\mathrm{p} 107 ; 7 \cdot 5 \%$ for $\mathrm{E} 2 \mathrm{~F}-4 ; 10 \%$ for cdk and cyclin blots. All gels were $10-\mathrm{cm}$ mini gels (Hoeffer Mighty Small II; AmershamPharmacia Biotech), blotted onto Immobilon P (Millipore, Watford, Herts, UK) and detected by enhanced chemiluminescence (ECL or ECL-Plus, Amersham-Pharmacia Biotech). The antibodies 
used were: anti-pRb (PMG3-245; PharMingen, Beckton Dickinson Co., Heidelberg, Germany); anti-p130, (C20), anti-p107 (C18), anti-E2F-1 (C20), anti-E2F-4 (C20), anti-p27 ${ }^{\mathrm{Kip} 1}$ (C19), and anti-cdk6 (C21) (Santa Cruz Biotech Inc., Santa Cruz, CA, USA).

\section{Immunocytochemistry}

Cells were immobilised on glass slides by cytocentrifugation $\left(5-10 \times 10^{4} /\right.$ slide; 700 r.p.m., 7 min (Cytocentrifuge 3, Shandon-Southern Ltd., Runcorn, Cheshire, UK)) and fixed in $\mathrm{CH}_{3} \mathrm{OH} /$ $0.6 \% \mathrm{H}_{2} \mathrm{O}_{2}$ for $10 \mathrm{~min}$ at $-20{ }^{\circ} \mathrm{C}$. The cells were permeabilised for $10 \mathrm{~min}$ at room temperature in $4 \mathrm{mM}$ sodium deoxycholate followed by a few seconds in $0.25 \%$ Triton X-100. After washing in Tris-buffered saline (TBS), the slides were incubated for $1 \mathrm{~h}$ in first antibody $(2 \mathrm{ng} / \mathrm{ml}$ in TBS) or antibody pre-incubated for $1 \mathrm{~h}$ with a 100 -fold molar excess of cognate peptide. The antibodies used were: anti-p107 (C19), anti-p130 (C20) or anti-E2F-4 (C20) (Santa-Cruz Biotech Inc.). The slides were washed in TBS, incubated for $1 \mathrm{~h}$ in mouse anti-rabbit immunoglobulin (1/20 in TBS), then $1 \mathrm{~h}$ with peroxidase-conjugated rabbit antimouse immunoglobulin (1/20 in TBS), and $1 \mathrm{~h}$ with mouse peroxidase-anti-peroxidase (1/10 in TBS) (all from DAKO Ltd., Ely, Cambs, UK) with three washes in TBS between each layer. The bound antibody was visualised with diaminobenzidine for 20 min, washed in tap water and counter-stained with Mayers Haemotoxylin for $10 \mathrm{~min}$, followed with tap water for $10 \mathrm{~min}$. The slides were then air-dried and mounted in DPX.

\section{RESULTS}

\section{Characterisation of granulosa lutein cells}

The GLC were isolated as described in Materials and Methods from the follicular fluid of women attending the Assisted Conception Unit for infertility treatment. In order to assess their purity, slides of each sample pre and post purification were prepared by cyto-centrifugation and stained with May-Grunwald-Giemsa (MGG) stain. The GLC are larger than the contaminating blood cells, granular in appearance and tend to form clumps (data supplied to reviewers but not shown). As part of the purification procedure the ficoll-purified cells were cultured overnight on plastic slides in RPMI-1640 medium containing 10\% (v/v) FCS. These cells adhere to the plastic within $2 \mathrm{~h}$ and become different morphologically in that they flatten and extend processes. In order to ascertain

www.endocrinology.org whether the purified cells were functionally viable, we assayed their ability to produce progesterone and oestradiol from pregnenolone and testosterone precursors. Cells alone produced minimal amounts of progesterone and oestradiol but when cultured in the presence of pregnenolone for $96 \mathrm{~h}$, progesterone production ranged from 200 to $850 \mathrm{pmol} / 2 \times 10^{4}$ cells $(n=11)$. Correspondingly, oestradiol production ranged from 15 to $62 \mathrm{pmol} / 2 \times 10^{4}$ cells when cultured in the presence of testosterone. Taken together, these data suggest that the isolated cells were functionally mature granulosa lutein cells.

\section{Cell cycle analysis}

The proliferative state of the purified GLC was assessed by flow cytometric analysis of their DNA content. Before purification it was not possible to distinguish the GLC adequately from contaminating blood cells based on their size (forward scatter) or granularity (side scatter) characteristics (compare Fig. 1A (GLC) with $\mathrm{B}, \mathrm{C}$, and $\mathrm{D}$ respectively). However, the purification method enabled us to analyse the DNA content of GLC which were $>95 \%$ pure. As shown in Fig. 1F, the GLC have a $2 \mathrm{n}$ DNA content which is characteristic of cells in $\mathrm{G}_{0} / \mathrm{G}_{1}$ and is the same as that obtained for non-dividing, differentiated primary haemopoietic cells such as monocytes (Fig. 1G) or neutrophils (Fig. $1 \mathrm{H}$ ), or for cells which are known to be in $\mathrm{G}_{0}$, such as peripheral blood T-lymphocytes (Fig. 1I). Proliferating T-lymphocytes are shown for comparison in Fig. 1J. Overall, the proportion of GLC in $G_{0} / G_{1}$ was $83 \cdot 8 \% \pm 8 \cdot 9 \%$ and $9 \cdot 2 \% \pm 8 \cdot 2 \%$ in $\mathrm{S}+\mathrm{G}_{2} / \mathrm{M}(n=7)$. Very few cells were detected with a sub-diploid DNA content (see $\mathrm{A}$ in Fig. 1F), which is usually characteristic of cells undergoing apoptosis $(7 \cdot 0 \% \pm 2 \cdot 6 \% ; n=7)$.

\section{Expression of proteins that regulate cell proliferation}

The cell cycle analyses showed that most, but not all, of the GLC isolates were in a non-dividing state $\left(n=3\right.$ of 7 with $<5 \%$ cells in $\left.\mathrm{S}+\mathrm{G}_{2} / \mathrm{M}\right)$, consistent with being terminally differentiated. In order to determine the molecular mechanisms involved, we probed Western blots for proteins that are known to regulate cell proliferation. GLC contain hypophosphorylated $\mathrm{pRb}$ and $\mathrm{p} 130$ forms 1 and 2 (Fig. 2A, B, lanes 4, 5; $n=22$ ) and no hyperphosphorylated forms of these proteins were detected even after exposing the blots $>10$ times longer (not shown). These forms of $\mathrm{pRb}$ (Fig. 2A, lane 3) and p130 (not shown) were also present in quiescent T-cells whereas hyperphosphorylated 

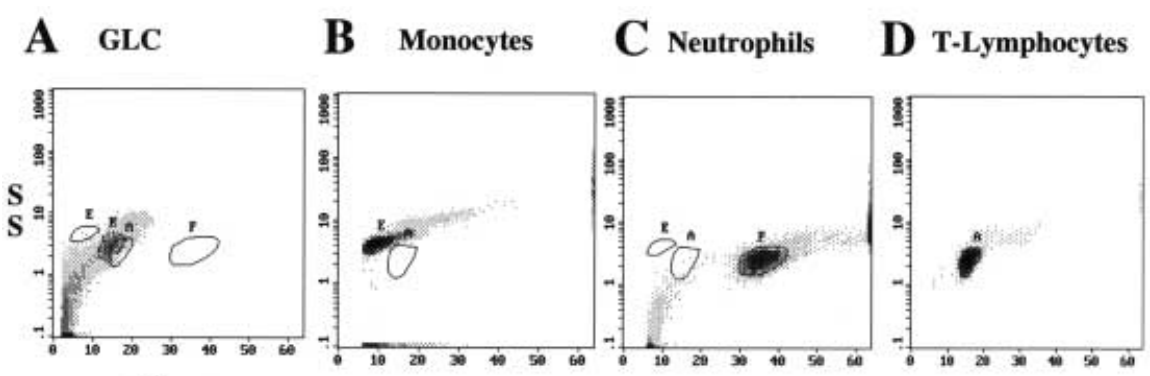

FS
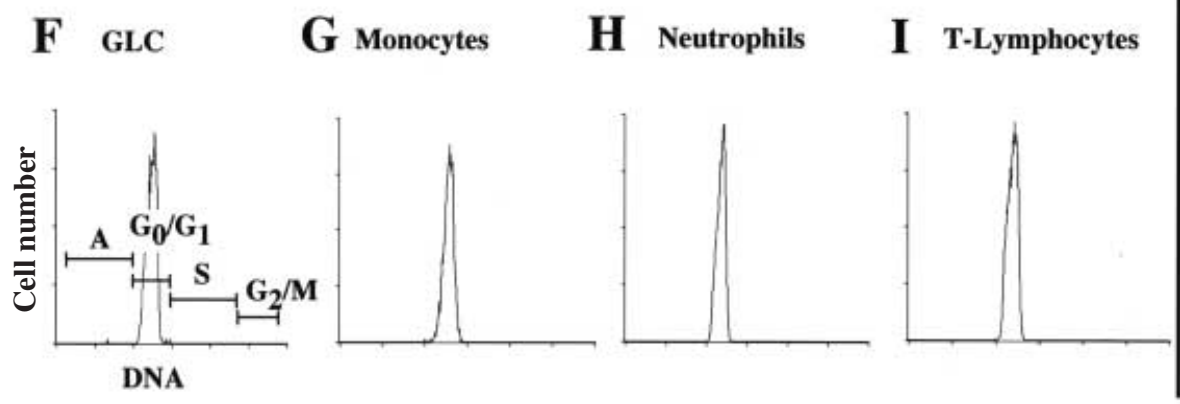

J Proliferating T-lymphocytes

FIGURE 1. Cell cycle analysis. Purified GLC, monocytes, neutrophils, and quiescent and proliferating T-lymphocytes were fixed with 70\% (v/v) ethanol, stained with PI and analysed by flow cytometry. Panels A to E show size (forward scatter (FS)) compared with granularity (side scatter (SS)) and the main populations in each are ringed. Panels $\mathrm{F}$ to $\mathrm{J}$ are of DNA content (PI staining) and the first panel (F) shows the linear gates set for determining the percentage of cells in $G_{0} / G_{1}, S$ and $G_{2} / M$ phases of the cell cycle as well as those with a sub- $G_{1}$ DNA content (A).

$\mathrm{pRb}$ and $\mathrm{p} 130$ form 3 were detected in samples of proliferating CD34+ or Daudi cells (Fig. 2A, B, lanes 6 and 3 respectively). No E2F-1 was detectable in GLC (Fig. 2A, lanes 4, 5; $n=3$ ), even after prolonged exposure (not shown), but E2F-1 was expressed in proliferating Daudi cells (Fig. 2A, lane 6). GLC do contain E2F-4 (Fig. 2A, lanes 4, 5; $n=15$ ), and the phosphorylated forms of E2F-4 present co-migrate with those in proliferating cells (lane 6) rather than the hyperphosphorylated form (lane 3) which we have shown is present in quiescent primary haemopoietic cells such as T- or B-lymphocytes or CD34+ cells (Williams et al. 1997a, Thomas et al. 1998, Van der Sman et al. 1999). We also detected the hypophosphorylated form of p107 in the GLC samples (Fig. 2A, lanes 4, $5 ; n=10)$. This is not due to proliferating cells contaminating the GLC as in one sample $<1.5 \%$ of cells were in $S$ or $G_{2} / M$ phases of the cell cycle. This was also confirmed by staining cytospins (see below). Hypophosphorylated p107 was detected in some freshly isolated preparations of peripheral blood T-lymphocytes (lane 3) and hyperphos- phorylated p107 was present in a sample of proliferating T-lymphocytes run on the same gel (lane 6). It is important to note that none of these signals was due to haemopoietic cells contaminating the GLC preparations. This was verified by analysing the same number of purified monocytes (M), lymphocytes (L) and neutrophils (N) (see Fig. legend) as contaminated the GLC preparations prior to the final adherance step.

The lack of E2F-1 expression and the presence in GLC of the hypophosphorylated forms of $\mathrm{pRb}$, p130 and p107 are consistent with their being out of cycle. We also probed blots for the cdk inhibitor, $\mathrm{p} 27^{\mathrm{Kip} 1}$, which has been reported to be expressed in terminally differentiated mouse GLC (Srivastava \& Pollard 1999). Human GLC also contain high levels of $\mathrm{p} 27^{\mathrm{Kip} 1}$ (Fig. $2 \mathrm{~B}$, lanes 4 and $5 ; n=5$ ), whereas it is poorly expressed in proliferating CD34+ cells (lane 3). For comparison, the blot was also probed for cdk6, which is expressed highly in proliferating CD34+ cells (lane 3 ) but at low levels in GLC (lanes 4 and $5 ; n=6)$. As before, the signals were not due to contaminating blood cells (lanes 1, 2, 6-9). 
A
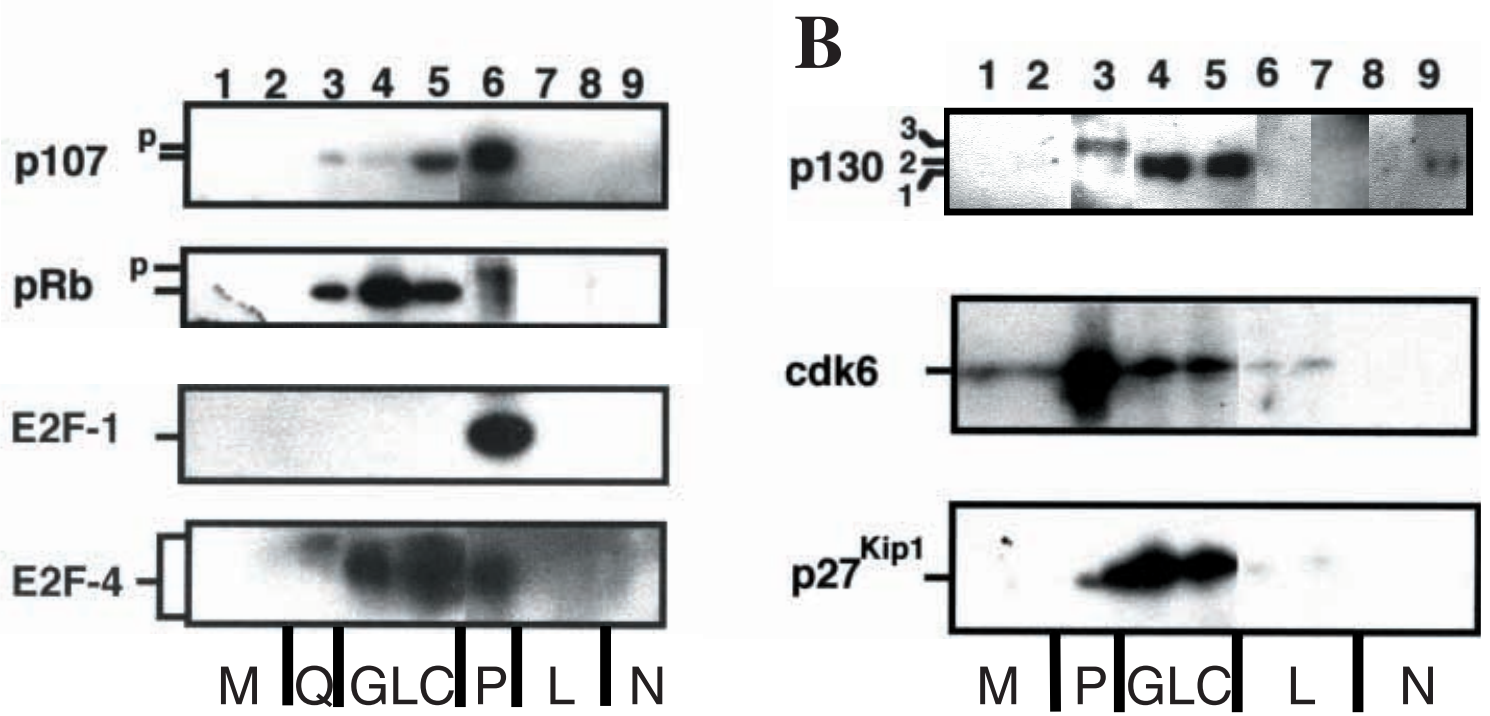

FIGURE 2. Expression of proteins that control cell proliferation. Western blots are shown for: (A) p107, pRb, E2F-1 and E2F-4 and (B) p130, cdk6 and p27 ${ }^{\mathrm{Kip} 1}$. The samples run on each blot were $2 \times 10^{5} \mathrm{GLC}(\mathrm{A}$ and B, lanes 4,5$)$, and the corresponding number of haemopoietic cells that contaminated each GLC sample prior to plastic adherence: monocytes (M: A and B, lanes 1 and $2(5 \%$ and 2.5\%)); resting T-lymphocytes (L: A, lanes 7 and 8 ; B, lanes 6 and 7 $(5 \%$ and $10 \%)$ ) and neutrophils (N: A, lane $9(40 \%)$; B, lanes 8 and $9(15 \%$ and $40 \%)$ ). Lysates of dividing and non-dividing cells were run as controls: A, lane 3: $2 \times 10^{5}$ quiescent CD34+ haemopoietic progenitor cells or $2 \times 10^{5}$ quiescent T-lymphocytes $(\mathrm{Q}) ; \mathrm{A}$, lane 6:1 $1 \times 10^{5}$ proliferating Daudi B-cell line $(\mathrm{P})$; B, lane 3: proliferating CD34+ progenitor cells $(\mathrm{P})$. The same samples were run on two blots that were cut in half and probed for $\mathrm{p} 107$ and $\mathrm{pRb}$ or E2F-1 and E2F-4 (panel A). Similarly, the blots in panel B were probed for cdk6 and p27 $7^{\mathrm{Kip} 1}$. $\mathrm{p}$ : hyperphosphorylated form of $\mathrm{p} 107$ or $\mathrm{pRb} ; 1,2,3$ : different phosphorylated forms of p130. (The nomenclature adopted for the different phosphorylated forms of p130 is that used by Mayol et al. 1995, 1996. Forms 1, 2 and 3 migrate in that order by one-dimensional SDS-PAGE, with form 3 migrating the slowest.)

\section{Activity of the $\mathbf{p R b}$ family}

The finding that p107 is expressed in GLC was surprising since this protein is not normally expressed in non-dividing cells and this prompted us to determine whether p107 and p130 were active in GLC. In order to assess their activity, we assayed for the ability of p107, p130 as well as pRb isolated from GLC to bind to an E2F DNA-binding site in a 'pull-down' assay. The hypophosphorylated forms of $\mathrm{pRb}$ and $\mathrm{p} 107$ as well as predominantly p130 form 2 bound to the E2 $\mathrm{F}^{\mathrm{WT}}$ DNA site (Fig. 3A-C, lane $1 ; n=3)$ but not to a mutant site $\left(\mathrm{E} 2 \mathrm{~F}^{\mathrm{MUT}}\right)$ (lane 2). The hyperphosphorylated forms of each protein that are present in proliferating T-lymphocytes are shown for comparison in Fig. 3A-C, lane 4. E2F-4 also bound to the same site (Fig. 3D, lane $1 ; n=4)$ and, as we have reported previously (Thomas et al. 1998, Van der Sman et al. 1999), the more highly phosphorylated forms of E2F-4 bound preferentially (compare with lanes 3 and 4). However, we did not detect E2F-1 bound to the $\mathrm{E} 2 \mathrm{~F}^{\mathrm{WT}}$ DNA site (not shown). Thus we conclude that in GLC, pRb, p130 and p107 are all

www.endocrinology.org active in that they, together with E2F-4, can all bind to an E2F DNA-binding site.

\section{Sub-cellular localisation}

Next, we determined whether p107 was expressed in all GLC in the population and whether its sub-cellular distribution was similar to that of p130. Cytocentrifuge slides stained with an antibody to p107 showed that p107 was expressed in almost all GLC in the population (Fig. 4A; $n=4$ ). The positive signal was abolished by blocking the primary antibody with its cognate peptide (data supplied to reviewers but not shown). As expected, p107 was not expressed in quiescent T-lymphocytes but was in T-lymphocytes proliferating in IL-2 (Fig. 4A). p130 was also expressed in all GLC and also in quiescent and proliferating T-lymphocytes (Fig. 4B; $n=3$ ). The staining of p130 in quiescent T-cells and GLC was predominantly nuclear and evenly distributed, while it was predominantly cytoplasmic in proliferating T-cells, as reported previously for other cell types (Verona et al. 1997). In contrast, the sub-cellular 
A

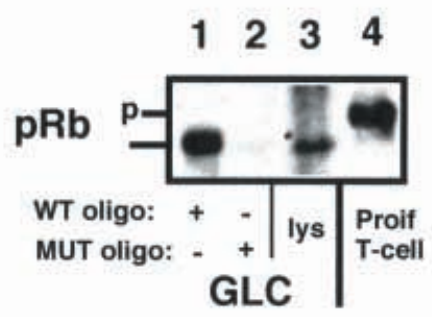

C

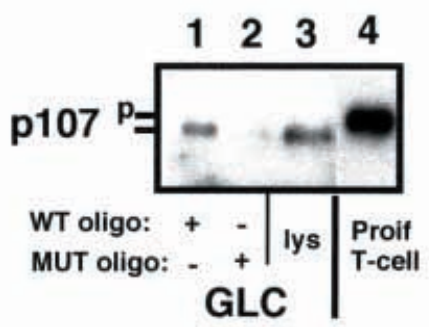

B

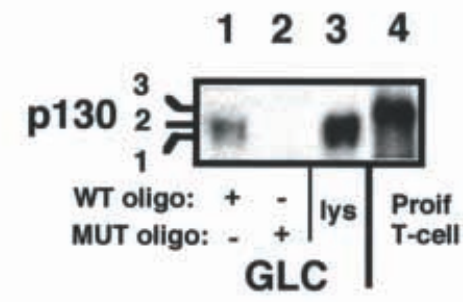

D

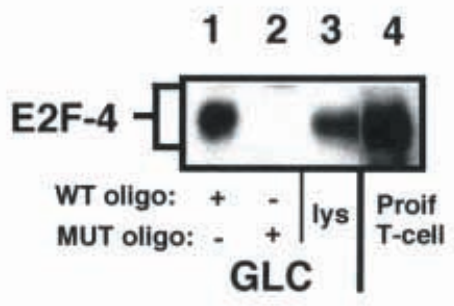

FIGURE 3. E2F complexes with p130, pRb and p107: E2F DNA pull-down assays. Lysates of $1 \times 10^{6}$ GLC (lanes 1 and 2) were incubated with the E2F mutant (MUT) DNA-binding site coupled to beads, followed by the wild-type E2F site (WT) as described in Materials and Methods, and the proteins bound were analysed by Western blotting. The Western blots were cut in half and the top probed for $\mathrm{p} 130, \mathrm{pRb}$ or $\mathrm{p} 107$ and the bottom for E2F-4. Total cell lysates (lys) of $1 \times 10^{5}$ GLC and proliferating T-lymphocytes (Proif T-cell) were run in lanes 3 and 4 respectively. Note that a shorter exposure is shown for lane 4 than for lanes 1-3 in panel C.

distribution of p107 was different: in GLC, p107 localised to a small number of sub-nuclear regions consistent with being localised to nucleoli (Fig. 4D), while p130 had an even nuclear distribution; only p130 was detectable in quiescent T-lymphocytes where it was nuclear; p130 was predominantly cytoplasmic in proliferating $\mathrm{T}$-lymphocytes while p107 was present in both nuclei and cytoplasm. The distribution of E2F-4 more closely resembled that of p130 than p107 in each case (Fig. 4C).

\section{DISCUSSION}

Granulosa cells are the somatic cells that nourish, provide metabolic support and participate in intra-follicular communication with their accompanying germ cell (oocyte). The granulosa cells are stimulated to proliferate, to differentiate and to luteinise in response to endocrine, paracrine and autocrine factors (reviewed in Amsterdam \& Selvaraj 1997). Recent studies on mice have shown the importance of a specific cyclin, cyclin D2, and a cdk inhibitor, $\mathrm{p} 27^{\mathrm{Kip} 1}$, in their proliferation and function. Further, these cell cycle regulators have been shown to be crucial for normal fertility. Cyclin D2 is absolutely required for the proliferation of immature granulosa cells in response to $\mathrm{FSH}$, which occurs during the early stages of their development (Sicinski et al. 1996). The granulosa cells from cyclin $\mathrm{D} 2^{-/-}$mice still differentiate in response to the late surge in LH but the oocytes are not ovulated and remain trapped in the corpora lutea. The p $27^{\mathrm{Kip} 1}$ protein is necessary for the timely withdrawal from the cell cycle which occurs normally during terminal differentiation of GLC. In the absence of the $p 27^{K i p 1}$ gene, luteal cells remain in cycle longer, oestradiol regulation is perturbed (Nakayama et al. 1996) and embryos fail to implant (Fero et al. 1996, Kiyokawa et al. 1996, Nakayama et al. 1996). Both cyclin D2 and $\mathrm{p} 27^{\mathrm{Kip} 1}$ regulate cdk activity which, in turn, control the activities of members of the $\mathrm{pRb}$ family and the E2F proteins to which they bind (reviewed by Thomas 1999). There is increasing 

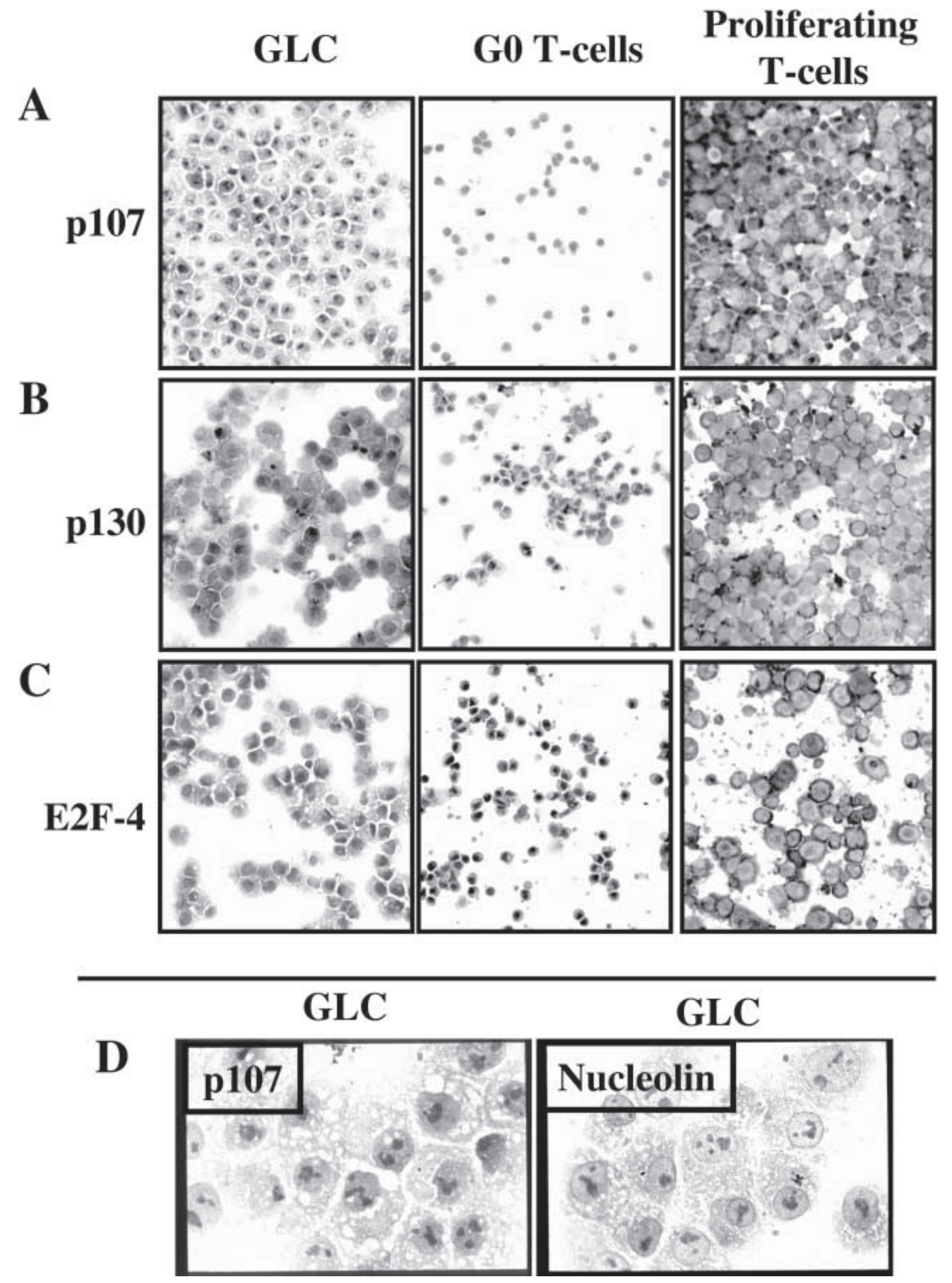

FIGURE 4. Subcellular localisation of p107, p130 and E2F-4. Cytocentrifuge slides of GLC, quiescent primary T-lymphocytes (G0 T-cells) and T-lymphocytes proliferating in IL-2 (Proliferating T-cells) were stained with antibodies to: (A) p107, (B) p130 and (C) E2F-4 and visualised with a peroxidase-conjugated second-layer system (APAAP) $(\times 40$ objective). The cells were counter-stained with methyl green. Signals obtained with each primary antibody were abolished by pre-incubation with a 100 -fold molar excess of the cognate peptide (not shown). (D) GLC stained for p107 and the nucleolar protein, nucleolin, at higher magnification $(\times 100$ objective $)$ are shown. 
evidence that $\mathrm{pRb}, \mathrm{p} 130$ and $\mathrm{p} 107$ have different functions in regulating cell proliferation: for example, p130 rather than $\mathrm{pRb}$ controls cell cycle exit in a B-cell line (Hoshikawa et al. 1998) and during cell cycle arrest in $G_{1}$ triggered by $\alpha$ interferon $(\alpha-\mathrm{IFN}), \mathrm{pRb}$ and $\mathrm{p} 130$ are activated by dephosphorylation in different cell cycle phases while p107 is dephosphorylated and then depleted (Thomas et al. 1998). In the study presented here we have determined which members of the $\mathrm{pRb}$ family are active in human terminally differentiated granulosa lutein cells. In order to be able to do this we developed a method for purifying these cells from follicular fluid which has enabled us to analyse their proliferative state by flow cytometry, the presence and phosphorylation state of particular proteins by Western blotting and the activity of E2F and the $\mathrm{pRb}$ family by E2F DNA pull-down assays.

Flow cytometric analysis of the DNA content of the purified GLC showed that most isolates were predominantly in $\mathrm{G}_{0} / \mathrm{G}_{1}$ and, in agreement with this, the GLC contained p27 $7^{\mathrm{Kip} 1}$ but not E2F-1. The GLC expressed E2F-4, which is not surprising since it is present in many quiescent and terminally differentiated cells in which it is repressed by being bound to $\mathrm{p} 130$ forms 1 and/or 2 (reviewed in Thomas 1999). E2F-4 is itself a phosphoprotein and the forms of E2F-4 which are present in GLC are the same as those in proliferating cells or, for example, in Daudi B-cells arrested in $\mathrm{G}_{1}$ by $\alpha$-IFN or by serum withdrawal (Thomas et al. 1998). We have detected these forms also in HL60 cells during differentiation (Thomas et al. 1998) and in differentiated primary haemopoietic cells such as monocytes or neutrophils (Williams et al. 1997b). In contrast, quiescent cells such as peripheral blood Tor B-lymphocytes or CD34+ haemopoietic progenitor cells contain a hyperphosphorylated form of E2F-4 (Williams et al. 1997b, Thomas et al. 1998, Van der Sman et al. 1999). This form, in association with p130, binds to an E2F DNA-binding site in preference to the hypophosphorylated forms of E2F-4 and we have suggested that hyperphosphorylated E2F-4 together with phosphorylated DP-1 bind the p130-E2F-4-DP-1 complex to the DNA (Van der Sman et al. 1999). Thus, the fact that GLC do not contain hyperphosphorylated E2F-4 is consistent with being terminally differentiated rather than being quiescent.

We detected all three members of the $\mathrm{pRb}$ family in GLC and each was able to bind to an E2F DNA-binding site. The GLC contained hypophosphorylated $\mathrm{pRb}$ and $\mathrm{p} 130$ forms 1 and 2 which are known to repress E2F activity in many different non-dividing cell types (see Thomas 1999). However, the GLC also contained hypophosphorylated p107. p107 is normally present in a hyperphosphorylated form in proliferating cells and it has been implicated in regulating E2F activity during $\mathrm{S}$ and $\mathrm{G}_{2} / \mathrm{M}$ phases of the cell cycle (reviewed in Thomas 1999). Non-dividing cells do not usually contain p107; for example, we have shown that p107 is depleted from Daudi B-cells during $\alpha$-IFNmediated cell cycle arrest and in HL60 myeloid cells during differentiation caused by retinoic acid (Thomas et al. 1998). In both cases, p107 is first dephosphorylated to a hypophosphorylated state and hypophosphorylated p107 is still detectable in Daudi cells $48 \mathrm{~h}$ after the addition of $\alpha$-IFN when the majority of cells are arrested in $G_{1}$. It is not known whether the hypophosphorylated p107 in these cells does indeed have a role to play in promoting cell cycle exit or whether its dephosphorylation is simply a consequence of cell cycle exit triggered by other proteins. However, in GLC, p107 is expressed in almost all cells in the population, as are p130 and E2F-4.p107 is active in binding an E2F DNA-binding site and the same is true for $\mathrm{p} 130, \mathrm{pRb}$ and $\mathrm{E} 2 \mathrm{~F}-4$. This is important as p107 cannot bind DNA in the absence of E2F and transfection studies with other cell types have shown that $\mathrm{pRb}, \mathrm{p} 130$ as well as p107 are capable of inhibiting E2F activity and arresting cell proliferation (Zhu et al. 1993, Thomas 1999). E2F activity is repressed in GLC as the gene encoding E2F-1, which is itself induced by E2F activity, is not expressed. It has been reported also that p107 regulates E2F activity during differentiation of murine primary lens cells or erythroleukaemic or adipocyte cell lines (Richon \& Venta-Perez et al. 1996, Richon et al. 1997, Rampalli et al. 1998). Further, co-transfection experiments of vectors expressing E2F-4 and p107 or p130 into U2OS cells caused nuclear localisation of E2F-4 but no apparent sub-nuclear distribution was reported (Lindeman et al. 1997). However, p107 has a distinctive sub-nuclear localisation in GLC consistent with localisation predominantly to nucleoli. In contrast, neither p130 nor E2F-4 localised to nucleoli but had a more even nuclear distribution.

In conclusion, the work presented here has shown that p107 is present in an active, hypophosphorylated form in GLC and we propose that it forms part of the mechanism whereby GLC exit the cell cycle during terminal differentiation. We and others have shown that cell cycle exit is a complex process involving inhibition of cdk activity by induction of cdk inhibitors and down-regulation of cyclins, activation of members of the $\mathrm{pRb}$ family by dephosphorylation and repression of $\mathrm{E} 2 \mathrm{~F}$ activity (reviewed in Thomas 1999). In addition to repressing $\mathrm{E} 2 \mathrm{~F}$-dependent transcription, which is 
mediated by RNA polymerase II, pRb regulates many other proteins, including repressing RNA polymerases I and III (Whyte 1997, Grana et al. 1998). p107 and p130 also regulate E2F activity (Thomas 1999) and repress the activity of RNA polymerase III (Larminie et al. 1997, Sutcliffe et al. 1999), but it is not known whether either regulate RNA polymerase I. From our immunostaining data, we suggest that p107 has a nucleolar function during terminal differentiation of human GLC, which could involve repressing $28 \mathrm{~S}, 18 \mathrm{~S}$ and $5 \cdot 8 \mathrm{~S}$ rRNA genes. We cannot rule out the possibility that some p107 also regulates E2F activity, but because of the more even nuclear distribution of E2F-4 we suggest that this is more likely to be carried out by p130. These data are important for our understanding of normal folliculogenesis and such information is pertinent for appreciation of the pathogenesis of granulosa and luteal cells tumours. Granulosa cell tumours have an elevated level of cyclin D2 (Sicinski et al. 1996) that would be expected to maintain the phosphorylation and inactivation of $\mathrm{pRb}, \mathrm{p} 130$ and also p107. Therefore, further studies are required to determine whether the activity of p107 is compromised in cells from granulosa cell tumours.

\section{ACKNOWLEDGEMENTS}

We thank Naina Chavda for immunophenotyping haematopoietic cells, Dr Pam Roberts for advice on purifying monocytes and neutrophils and Arnold Pizzey for flow cytometry. We also thank Dr P Surhal, Sally Merchant and other members of the Assisted Conception Unit for providing us with follicular fluid. This work was supported by the Heller Trust (C G) and the Kay Kendall Leukaemia Trust (N S B T).

\section{REFERENCES}

Amsterdam A \& Selvaraj N 1997 Control of differentiation, transformation, and apoptosis in granulosa cells by oncogenes, oncoviruses, and tumor suppressor genes. Endocrine Reviews 18 435-461.

Bukovsky A, Caudle MR, Keenan JA, Wimalansena J, Foster JS \& VanMeter SE 1995 Quantitative evaluation of the cell cycle-related retinoblastoma protein and localization of Thy-1 differentiation protein and macrophages during follicular development and atresia, and in human corpora lutea. Biology of Reproduction 52 776-792.

Darne FJ, McGarrigle HHG \& Lachelin GCL 1989 Diurnal variation of plasma and saliva oestrogen, progesterone, cortisol and plasma dehydroepiandrosterone sulphate in late pregnancy. European Fournal of Obstetrics and Gynecology and Reproductive Biology 32 57-66.
Devalia V, Thomas NSB, Roberts PJ, Jones HM \& Linch DC 1992 Down-regulation of human protein kinase C alpha is associated with terminal neutrophil differentiation. Blood $\mathbf{8 0}$ $68-76$.

Fero ML, Rivkin M, Tasch M, Porter P, Carow CE, Firpo E, Polyak K, Tsai LH, Broudy V, Perlmutter RM, Kaushansky K \& Roberts JM 1996 A syndrome of multiorgan hyperplasia with features of gigantism, tumorigenesis, and female sterility in p27(Kip1)-deficient mice. Cell $\mathbf{8 5}$ 733-744.

Grana X, Garriga J \& Mayol X 1998 Role of the retinoblastoma protein family, pRB, p107 and p130 in the negative control of cell growth. Oncogene 17 3365-3383.

Hillier SG, Smyth CD, Whitelaw PF, Miro F \& Howles CM 1995 Gonadotrophin control of follicular function. Hormone Research 43 216-223.

Hoshikawa Y, Mori A, Amimoto K, Iwabe K \& Hatakeyama M 1998 Control of retinoblastoma protein-independent hematopoietic cell cycle by the pRB-related p130. PNAS 95 8574-8579.

Kiyokawa H, Kineman RD, Manova-Todorova KO, Soares VC, Hoffman ES, Ono M, Khanam D, Hayday AC, Frohman LA \& Koff A 1996 Enhanced growth of mice lacking the cyclin-dependent kinase inhibitor function of p27(Kip1). Cell 85 721-732.

Kumar TR, Wang Y, Lun N \& Matzuk MM 1997 Follicle stimulating hormone is required for ovarian follicle maturation but not male fertility. Nature Genetics $\mathbf{1 5}$ 201-204.

Larminie CGC, Cairns CA, Mital R, Martin K, Kouzarides T, Jackson SP \& White RJ 1997 Mechanistic analysis of RNA polymerase III regulation by the retinoblastoma protein. EMBO Yournal 16 2061-2071.

Lindeman GJ, Gaubatz S, Livingston DM \& Ginsberg D 1997 The subcellular localization of E2F-4 is cell-cycle dependent. PNAS 94 5095-5100.

Mason AJ, Pitts SL, Nikolics K, Szonyi E, Wilcox JN, Seeburg PH \& Sterart TA 1986 The hypogonadal mouse: reproductive functions restored by gene therapy. Science 234 1372-1378.

Mayol X, Garriga T \& Grana X 1995 Cell cycle-dependent phosphorylation of the retinoblastoma-related protein $\mathrm{p} 130$. Oncogene 11 801-808.

Mayol X, Garriga T \& Grana X 1996 G1 cyclin/CDKindependent phosphorylation and accumulation of p130 during the transition from G1 to G0 lead to its association with E2F-4. Oncogene 13 237-246.

Nakayama K, Ishida N, Shirane M, Inomata A, Inoue T, Shishido N, Horii I, Loh DY \& Nakayama K 1996 Mice lacking p27(Kip1) display increased body size, multiple organ hyperplasia, retinal dysplasia, and pituitary tumors. Cell 85 707-720.

Rampalli AM, Gao CY, Chauthaiwale VM \& Zelenka PS 1998 $\mathrm{pRb}$ and p107 regulate E2F activity during lens fiber cell differentiation. Oncogene 16 399-408.

Ranieri DM, Quinn F, Makhlouf A, Khadum I, Ghutmi W, McGarrigle H, Davies M \& Serhal P 1998 Simultaneous evaluation of basal follicle-stimulating hormone and 17 beta-estradiol response to gonadotropin-releasing hormone analogue stimulation: an improved predictor of ovarian reserve. Fertility and Sterility 70 227-233.

Richon VM \& Venta-Perez G 1996 Changes in E2F DNA-binding activity during induced erythroid differentiation. Cell Growth and Differentiation 7 31-42.

Richon VM, Lyle RE \& McGehee Jr RE 1997 Regulation and expression of retinoblastoma proteins p107 and p130 during 3T3-L1 adipocyte differentiation. Fournal of Biological Chemistry 272 10117-10124. 
Sicinski P, Donaher JL, Geng Y, Parker SB, Gardner H, Park MY, Robker RL, Richards JS, McGinnis LK, Biggers JD, Eppig JJ, Bronson RT, Elledge SJ \& Weinberg RA 1996 Cyclin D2 is an FSH-responsive gene involved in gonadal cell proliferation and oncogenesis. Nature $384470-474$.

Srivastava M \& Pollard HB 1999 Molecular dissection of nucleolin's role in growth and cell proliferation: new insights. FASEB Fournal 13 1911-1922.

Sutcliffe JE, Cairns CA, McLees A, Allison SJ, Tosh K \& White RJ 1999 RNA polymerase III transcription factor IIIB is a target for repression by pocket proteins p107 and p130. Molecular Cell Biology 19 4255-4261.

Thomas NSB 1999 Cell cycle regulation. In Textbook of Malignant Haematology, pp 133-152. Eds L Degos, D Linch \& B Lowenberg. London: Martin Dunitz Publishers.

Thomas NSB, Pizzey AR, Tiwari S, Williams CD \& Yang J $1998 \mathrm{p} 130, \mathrm{p} 107$, and $\mathrm{pRb}$ are differentially regulated in proliferating cells and during cell cycle arrest by alpha-interferon. Fournal of Biological Chemistry 273 23659-23667.

Van der Sman J, Thomas NSB \& Lam EWF 1999 Modulation of $\mathrm{E} 2 \mathrm{~F}$ complexes during $\mathrm{G} 0$ to $\mathrm{S}$ phase transition in human primary B-lymphocytes. Fournal of Biological Chemistry 274 12009-12016.
Verona R, Moberg K, Estes S, Starz M, Vernon JP \& Lees JA $1997 \mathrm{E} 2 \mathrm{~F}$ activity is regulated by cell cycle-dependent changes in subcellular localization. Molecular Cell Biology 17 $7268-7282$.

Whyte RJ 1997 Regulation of RNA polymerases I and III by the retinoblastoma protein: a mechanism for growth control? Trends in Biochemical Sciences 22 77-80.

Williams CD, Linch DC, Sorensen TS, La Thangue NB \& Thomas NSB $1997 a$ The predominant E2F complex in human primary haemopoietic cells and in AML blasts contains E2F-4, DP-1 and p130. British Fournal of Heamatology 96 688-696.

Williams CD, Watts M, Linch DC \& Thomas NSB $1997 b$ Characterization of cell cycle status and E2F complexes in mobilized CD34+ cells before and after cytokine stimulation. Blood 90 194-203.

Zhu L, van den Heuvel S, Helin K, Fattaey A, Ewen M, Livingston D, Dyson N \& Harlow E 1993 Inhibition of cell proliferation by $\mathrm{p} 107$, a relative of the retinoblastoma protein. Genes and Development 7 1111-1125.

RECEIVED 22 May 2000 